\title{
EXPLOITATION OF TRICHODERMA SPECIES ON THE GROWTH OF PYTHIUM APHANIDERMATUM IN CHILLI
}

\section{A. Muthukumar*; A. Eswaran; K. Sanjeevkumas}

Department of Plant Pathology, Faculty of Agriculture, Annamalai University, Annamalainagar, Chidambaram, Tamil Nadu, India.

Submitted: August 10, 2010; Approved: May 30, 2011.

\begin{abstract}
Damping-off of chilli caused by Pythium aphanidermatum is a major nursery disease in vegetables. In vitro experiments evaluated the effect of eight isolates of Trichoderma species (from chilli rhizosphere) were tested against $P$. aphanidermatum. All the Trichoderma species had varied antagonistic effects against the pathogen. Among them, $\mathrm{TVC}_{3}$ recorded maximum growth inhibition of $P$. aphanidermatum and produced more amounts of volatile and non-volatile metabolites. The culture filtrate of the Trichoderma isolate $\mathrm{TVC}_{3}$ recorded complete inhibition on the mycelial growth of pathogen at $15 \%$ concentration. Moreover, chilli seeds treated with culture filtrate of the isolate $\mathrm{TVC}_{3}$ recorded maximum germination percentage, shoot length, root length and vigour index of chilli. The study identified the Trichoderma isolate $\left(\mathrm{TVC}_{3}\right)$ performed well in inhibiting the mycelial growth of pathogen as well as increased the plant growth in chilli.
\end{abstract}

Key words: Capsicum annuum, Trichoderma species, growth inhibition, secondary metabolites, Plant growth promotion

\section{INTRODUCTION}

Chilli is a universal spice of India. It belongs to the genus Capsicum and the family solanaceae which is popularly known as "Red Pepper". The crop chilli is known for the red colour pigment "Capsanthin" and the pungency is attributed to "Capsaicin". Apart from it, chilli is also well known for the vitamins such as $\mathrm{A}, \mathrm{C}$ and $\mathrm{E}$. Though chilli plays a vital role in increasing the national economy, still the productivity and foreign exchange realized through chilli can be increased by the management of various diseases caused by pathogens of fungal, bacterial and viral origin. Among the fungal diseases, damping-off caused by Pythium species cause more than 60 per cent mortality of seedlings both in nursery and main field (20).

Management of Pythium is very difficult due to its wide host range, soil-borne nature and prolonged survival of propagules in the soil. Traditionally, this disease is controlled by the application of synthetic fungicides. But the indiscriminate use of fungicides resulted in the accumulation of residual toxicity, environmental pollution and altered the biological balance in the soil by over killing the non-targeted microorganisms. Besides development of resistance to fungicides in the pathogen Pythium spp. (23).

It is therefore essential to develop an effective,

*Corresponding Author. Mailing address: Department of Plant Pathology, Faculty of Agriculture, Annamalai University, Annamalainagar 608002 , Chidambaram, Tamil Nadu, India.; E-mail: muthu78ap@yahoo.co.in 
cheap and environmentally safe non-chemical method for the management of damping-off disease. Hence, Biological control has been developed as an alternative to synthetic fungicides and considerable success has been achieved by utilizing antagonistic microorganisms for controlling soilborne pathogens. The need for alternative control strategies, particularly those involving biological control, has increased greatly in the past two decades. Growth inhibition of Pythium species by the Trichoderma metabolites has been well researched $(15,18)$. The successful application of Trichoderma species for the management of damping-off caused by Pythium species in chilli and tomato has been previously reported $(14,19)$. The objectives of the present study were (1) Isolation and identification of pathogen, (2) Isolation of Trichoderma species from chilli rhizosphere and tested for its efficacy against $P$. aphanidermatum (3) To study the morphological characteristics of Trichoderma species (4) Efficacy of seed treatment with Trichoderma species on chilli seedling growth.

\section{MATERIALS AND METHODS}

\section{Plant materials}

Chilli variety 'Co-1' was obtained from the Department of vegetable crops, Horticultural College and Research Institute, Tamil Nadu Agricultural University (TNAU), Coimbatore, Tamil Nadu, India was used for the entire study.

\section{Isolation, maintenance and identification of pathogen}

The pathogenic fungal strain used in all the experiments was isolated from the soil of a nursery in Annamalainagar, purified in plain agar by the single hyphal tip method. A small block of agar medium from distal end of a colony growth in potato dextrose agar medium (PDA) was cut and re-inoculating the block on $2.5 \%$ water agar medium in a Petri plate to obtain a colony of about $1 \mathrm{~cm}$ diameter. Then the whole agar medium in the Petri plate was replaced upside-down with a flamed forceps in the same Petri plate and incubated until the colony reached before the plate wall, during this process the mycelia penetrate the agar medium without the contaminating bacteria and reach the top of the agar medium. A thin piece of agar containing a single hyphal tip of the desired fungus was taken from the surface of the margin of the colony on water agar medium under the microscope and transfer to PDA slant for maintaining the fungus at $28 \pm 2^{\circ} \mathrm{C}$ by regular sub culturing (30). The pathogen was identified as $P$. aphanidermatum based on the sporangial character (39).

\section{Isolation and identification of Trichoderma species}

Soil samples were collected from chilli rhizosphere at eight different chilli growing tracts of Tamil Nadu, India. For rhizospheric soil, plant was gently and carefully uprooted, soil tightly adhering the roots was collected, randomly selected, mixed and one forth part was used as composite rhizospheric soil sample of the region. The $\mathrm{pH}$ of soil was determined in 1:2 (soil:water) ratio, keeping $30 \mathrm{~min}$ as equilibration time.

Collected soil samples were air dried for $4 \mathrm{~h}$ and isolation was done by serial dilution technique. Trichoderma selective medium (TSM) was used for isolation of the isolates of Trichoderma (6). $1 \mathrm{~mL}$ soil suspension was taken with the help of $5 \mathrm{~mL}$ sterilized pipette and poured on the Petri plate seeded with TSM. The plates were incubated at $28 \pm 2^{\circ} \mathrm{C}$ for 5 days. Observation on the appearance of colonies was recorded from $3^{\text {rd }}$ to $5^{\text {th }}$ day. Individual colonies were picked up and maintained in pure culture for further study. The Trichoderma species were identified and examined under compound microscope on the basis of their cultural and morphological characters (27) and the cultures were maintained on PDA slants at $4^{\circ} \mathrm{C}$ for further study. Total of eight Trichoderma isolates were obtained and identified isolates were designated as $\mathrm{TVC}_{1}$, $\mathrm{TVC}_{2}, \mathrm{TVC}_{3}, \mathrm{TVC}_{4}, \mathrm{TVC}_{5}, \mathrm{THC}_{1}, \mathrm{THC}_{2}$ and $\mathrm{THC}_{3}$.

\section{Colony growth inhibition assay}

The antagonistic activity of Trichoderma species against $P$. aphanidermatum was tested by dual culture technique (32) 
using PDA medium. Each treatment was replicated four times with five plates per replication. Periodical observations on the growth of Trichoderma species and their ability to colonize the pathogen were recorded and also per cent inhibition of mycelial growth of pathogen was calculated by using the formula (38).

Per cent inhibition $(\mathrm{I})=\mathrm{C}-\mathrm{T} / \mathrm{C} \times 100$

Where, $\mathrm{C}-$ Growth of pathogen in control plates

$\mathrm{T}$ - Growth of pathogen in dual culture plates

I - Per cent inhibition in mycelial growth.

\section{Morphological studies}

The colony characteristics such as colony appearance, radial growth, conidial length and width and sporulation pattern were examined from cultures grown in darkness at $30^{\circ} \mathrm{C}$ for $96 \mathrm{~h}$ on PDA. Four plastic Petri plates, each containing $20 \mathrm{~mL}$ of media were used for each Trichoderma isolates. For analysis of colony characteristics and growth rate, mycelial discs were taken from the actively growing margin of different Trichoderma isolate grown for 3 days on PDA. The 5 $\mathrm{mm}$ diameter mycelial disc was placed at approximately $5 \mathrm{~mm}$ distance from the edge of $84 \mathrm{~mm}$ diameter Petri plate. The Petri plates were incubated in darkness at $30^{\circ} \mathrm{C}$, colony radial growth was measured at $24 \mathrm{~h}$ intervals until the colony reached the edge of Petri plate.

All micromorphological date were examined on cultures grown on PDA and 2\% Malt extract agar (MEA) for 7 days at 20 to $22^{\circ} \mathrm{C}$. The examination and measurements of conidial length and width were made from slide preparations stained with $3 \% \mathrm{KOH}$, which was subsequently replaced by water as the microscope preparation dried. For direct microscopic observations, 30 units of each character were measured with the exception of chlamydospores, of which 30 were not located in some cultures. Phase contrast and interference contrast microscopy were utilized in the study (26). The spore intensity was measured by using haemocytometer.

\section{Assay of production of volatile and non-volatile metabolites}

Production of volatile and non-volatile metabolites from Trichoderma species against $P$. aphanidermatum was tested following the method $(5,4,9)$.

\section{Volatile metabolites}

Trichoderma species isolates were inoculated in the centre of the Petri plate containing PDA by placing fresh $5 \mathrm{~mm}$ diameter mycelial disc taken from 5 days old grown on PDA with the help of a needle. Immediately after, the lid of each plate was replaced by the bottom of a plate containing PDA inoculated with $5 \mathrm{~mm}$ diameter mycelial disc of the pathogen taken from 3 days old grown on PDA. The two plates were sealed together with adhesive tape and incubated at $28 \pm 2{ }^{\circ} \mathrm{C}$. Each treatment had four replications. Suitable control was also maintained. The colony diameter of the pathogen was measured $48 \mathrm{~h}$ after incubation and compared with that of the control plates.

\section{Non-volatile metabolites}

A single sterile cellophane disc was placed aseptically over PDA in each Petri plate and left over night. Mycelial disc of $5 \mathrm{~mm}$ cut from actively growing culture of each isolate of Trichoderma was placed in the centre of the cellophane disc. The plates were incubated at $28 \pm 2^{\circ} \mathrm{C}$ for $48 \mathrm{~h}$. Then the cellophane disc along with adhering fungus was carefully removed and a $5 \mathrm{~mm}$ diameter mycelial disc of pathogen obtained from 3 days old grown on PDA, it was placed immediately on the medium in the centre of the plate. Each treatment had four replications. Suitable control was also maintained. The colony diameter of the pathogen was measured after $48 \mathrm{~h}$ of incubation and per cent inhibition was calculated.

\section{Inhibitory effect of the culture filtrates}

Trichoderma species were grown for 10 days at room temperature $\left(28 \pm 2^{\circ} \mathrm{C}\right)$ in Erlenmeyer flasks containing $50 \mathrm{~mL}$ 
of sterilized potato dextrose broth (PDB). The fungal cells were then removed from each culture by filtering first through two layers of muslin cloth and then through a $0.2 \mu \mathrm{m}$ Millipore filter. The filtrate thus obtained was used for the studies.

\section{Culture filtrates on the mycelial growth of $P$. aphanidermatum}

The culture filtrates of different Trichoderma species were separately incorporated into PDA medium at 5, 10 and 15 per cent by adding the calculated quantity of the culture filtrate to the medium by means of a sterile pipette. The amended media were transferred to sterile Petri plates separately at the rate of $15 \mathrm{~mL}$ and allowed to solidify. Each plate was inoculated at the centre with 3 days old $(5 \mathrm{~mm})$ culture disc of $P$. aphanidermatum grown on PDA. Four replications were maintained for each treatment. Sterile water served as control. The diameter of the mycelial growth (in $\mathrm{mm}$ ) of $P$. aphanidermatum was measured at $48 \mathrm{~h}$ after incubation.

\section{Effect of Trichoderma species on chilli growth in vitro}

Preparation of inoculum: The fungal antagonist Trichoderma species $\left(\mathrm{TVC}_{1}, \mathrm{TVC}_{2}, \mathrm{TVC}_{3}, \mathrm{TVC}_{4}, \mathrm{TVC}_{5}\right.$, $\mathrm{THC}_{1}, \mathrm{THC}_{2}$ and $\mathrm{THC}_{3}$ ) were multiplied in Trichoderma special broth (TSB) by inoculating a disc of actively growing mycelium and incubating for 15 days. Then the mycelial mats along with the spores were harvested by filtering through Whatman No.1 filter paper and the filtrate was mixed with sterile distilled water to produce colonies of $3 \times 10^{8} \mathrm{CFU} \mathrm{mL}^{-1}$.

Seed treatment: Seeds of chilli were surface sterilized with $2 \%$ sodium hypochlorite for 30 seconds, rinsed in sterile distilled water and air dried overnight. Ten $\mathrm{mL}$ of biocontrol inoculum containing $3 \times 10^{8} \mathrm{CFU} \mathrm{mL}^{-1}$ was placed in a Petri plate. One hundred mg of carboxy methyl cellulose (CMC) was added as an adhesive material. One gram of seeds was soaked in $10 \mathrm{~mL}$ of biocontrol suspension for $2 \mathrm{~h}$ and air dried overnight in a sterile Petri plate.

Plant growth promotion: The plant growth promoting activity of Trichoderma species was assessed based on the seedling vigour index by the standard roll towel method (12). Seed treatment was done as above. Twenty five seeds were placed on presoaked germination paper. The seeds were held in position with another presoaked germination paper strip and gently pressed. The polythene sheet along with the seeds was then rolled up and incubate in a growth chamber for 10 days. Four replications were carried out for each treatment. The seeds treated with sterile water served as control. The root length and shoot length of individual seedlings were measured after 15 days of inoculation with ruler and the per cent germination of the seeds was calculated. The seedling vigour index was calculated using the formula. Vigour Index $=($ Mean root length + mean shoot length $\times \%$ germination) (1).

\section{Statistical analysis}

All the experiments were of completely randomized design (CRD) and repeated twice. To determine the effect of each Trichoderma species on the radial growth of pathogen, the per cent reduction compared with the experimental controls was calculated. Data were subjected to analyses of variance and treatment means were compared by an appropriate Duncan's multiple range test $(\mathrm{P}<0.05)$.

\section{RESULTS}

\section{In vitro inhibition of $P$. aphanidermatum}

The eight isolates of Trichoderma species tested for the mycelial growth of $P$. aphanidermatum. Of these, isolate from chilli rhizosphere $\left(\mathrm{TVC}_{3}\right)$ exhibited maximum growth inhibition of $P$. aphanidermatum $(88.0 \%)$ compared with the control, followed by $\mathrm{THC}_{1}(83.9 \%)$ and $\mathrm{TVC}_{5}(80.0 \%)$ (Table 1). 
Table 1. In vitro efficacy of Trichoderma species against $P$. aphanidermatum in the dual culture tests.

\begin{tabular}{lcc}
\hline \multicolumn{1}{c}{ Trichoderma isolate } & Mycelial growth of the pathogen (mm) & Reduction over control (\%) \\
\hline $\mathrm{TVC}_{1}$ & $23.0 \mathrm{~d}^{\mathrm{l}}$ & 74.1 \\
$\mathrm{TVC}_{2}$ & $42.0 \mathrm{~h}$ & 52.6 \\
$\mathrm{TVC}_{3}$ & $10.7 \mathrm{a}$ & 88.0 \\
$\mathrm{TVC}_{4}$ & $27.0 \mathrm{e}$ & 70.0 \\
$\mathrm{TVC}_{5}$ & $17.7 \mathrm{c}$ & 80.0 \\
$\mathrm{THC}_{1}$ & $14.3 \mathrm{~b}$ & 83.9 \\
$\mathrm{THC}_{2}$ & $40.7 \mathrm{~g}$ & 54.1 \\
$\mathrm{THC}_{3}$ & $30.0 \mathrm{f}$ & 66.2 \\
Control & $88.7 \mathrm{i}$ & - \\
${ }_{\text {TVC: } \text { Trichoderma viride from chilli rhizosphere, THC: Trichoderma harzianum from chilli rhizosphere. }}$ & \\
${ }^{1}$ Means of four replicates. Values in each column followed by the same letter are not significantly different according to the DMRT method \\
(P $<0.05)$.
\end{tabular}

\section{Micromorphological characteristics of Trichoderma species}

Differences in micromorphological characteristics of eight Trichoderma species were described in Table 2. Conidia of Trichoderma species $\mathrm{TVC}_{3}(3.2 \times 3.3 \mu \mathrm{m}$; L/W ratio of $3.4 \mu \mathrm{m})$ were larger than those of the other species and had a shape of ellipsoidal to obovoid. The most obvious difference in conidia was their shape, which is to some extent reflected by the L/W ratio of the conidia. Conidia of Trichoderma species $\mathrm{TVC}_{2}$
$(2.7 \times 2.9 \mu \mathrm{m}), \mathrm{TVC}_{4}(2.9 \times 2.8 \mu \mathrm{m})$ and $\mathrm{THC}_{2}(2.3 \times 2.8 \mu \mathrm{m})$ were conspicuously globose to broadly ellipsoidal and had a length/width $(\mathrm{L} / \mathrm{W})$ ratio of $2.8,2.9$ and $2.6 \mu \mathrm{m}$, respectively. Conidia of Trichoderma species $\mathrm{TVC}_{1}(2.7 \times 2.8 \mu \mathrm{m})$ and $\mathrm{THC}_{1}$ $(3.0 \times 3.0 \mu \mathrm{m})$ were ellipsoidal and had a L/W ratio of 2.8 and $3.0 \mu \mathrm{m}$, respectively and those of $\mathrm{TVC}_{5}(2.9 \times 3.2 \mu \mathrm{m})$ and $\mathrm{THC}_{3}(2.8 \times 3.2 \mu \mathrm{m})$ were subglobose to ellipsoidal and had a $\mathrm{L} / \mathrm{W}$ ration of 3.1 and 3.0 , respectively.

Table 2. Morphological characteristics of Trichoderma species isolated from chilli rhizosphere.

\begin{tabular}{|c|c|c|c|c|c|}
\hline \multirow{3}{*}{ Species } & \multicolumn{2}{|c|}{$4^{\text {th }}$ day after inoculation } & \multirow{3}{*}{$\begin{array}{c}\begin{array}{c}\text { Radial } \\
\text { growth } \\
\text { (mm) }\end{array} \\
3^{\text {rd }} \text { day }\end{array}$} & \multirow{2}{*}{\multicolumn{2}{|c|}{ Conidial morphology }} \\
\hline & \multirow[t]{2}{*}{ Colony character } & \multirow{2}{*}{$\begin{array}{c}\text { Spore intensity } \\
\text { (Numbers/5 mm disc) }\end{array}$} & & & \\
\hline & & & & Shape & $\mathbf{L} / \mathbf{W}(\boldsymbol{\mu m})$ \\
\hline $\mathrm{TVC}_{1}$ & Deep green sporulation & $12-18 \times 10^{8}\left(15 \times 10^{8}\right)$ & 88.0 & ellipsoidal & $2.7 \times 2.8(2.8)^{1}$ \\
\hline $\mathrm{TVC}_{2}$ & Dull green sporulation & $8-10 \times 10^{8}\left(9 \times 10^{8}\right)$ & 83.3 & $\begin{array}{c}\text { globose to broadly } \\
\text { ellipsoidal }\end{array}$ & $2.7 \times 2.9(2.8)$ \\
\hline $\mathrm{TVC}_{3}$ & Dark green sporulation & $15-18 \times 10^{8}\left(16.5 \times 10^{8}\right)$ & 90.0 & ellipsoidal to obovoid & $3.2 \times 3.3(3.4)$ \\
\hline $\mathrm{TVC}_{4}$ & Green to bright green sporulation & $6-10 \times 10^{8}\left(8 \times 10^{8}\right)$ & 87.7 & $\begin{array}{c}\text { globose to broadly } \\
\text { ellipsoidal }\end{array}$ & $2.9 \times 2.8(2.9)$ \\
\hline $\mathrm{TVC}_{5}$ & Complete dark green sporulation & $14-17 \times 10^{8}\left(15.6 \times 10^{8}\right)$ & 89.0 & subglobose to ellipsoidal & $2.9 \times 3.2(3.1)$ \\
\hline $\mathrm{THC}_{1}$ & Dark green sporulation & $13-17 \times 10^{8}\left(15 \times 10^{8}\right)$ & 88.3 & ellipsoidal & $3.0 \times 3.0(3.0)$ \\
\hline $\mathrm{THC}_{2}$ & Dark green to dull blackish green sporulation & $12-15 \times 10^{8}\left(13.5 \times 10^{8}\right)$ & 88.7 & $\begin{array}{c}\text { globose to broadly } \\
\text { ellipsoidal }\end{array}$ & $2.3 \times 2.8(2.6)$ \\
\hline $\mathrm{THC}_{3}$ & Dull green sporulation & $5-9 \times 10^{8}\left(7 \times 10^{8}\right)$ & 84.0 & subglobose to ellipsoidal & $2.8 \times 3.2(3.0)$ \\
\hline
\end{tabular}

\section{Growth characters and sporulation}

Results from in vitro tests showed that the complete radial growth was observed in Trichoderma species $\mathrm{TVC}_{3}(90.00$ $\mathrm{mm})$ which was significantly greater than that of the other Trichoderma species and had a dark green sporulation on $4^{\text {th }}$ day after inoculation with spore intensity of $16.5 \times 10^{8}$. This was 
followed by Trichoderma species $\mathrm{TVC}_{5}(89.00 \mathrm{~mm}$; dark green sporulation and $\left.15.6 \times 10^{8}\right)$ and $\mathrm{THC}_{2}(88.70 \mathrm{~mm}$; dark green to dull blackish sporulation and $13.5 \times 10^{8}$ ). Whereas the Trichoderma species $\mathrm{TVC}_{2}$ and $\mathrm{THC}_{3}$ shows moderate growth $(83.3 ; 84.00 \mathrm{~mm})$ with colony character of dull green sporulation to green sporulation and had a spore intensity of $9 \times 10^{8}$ and $7 \times 10^{8}$, respectively.

\section{Volatile and non-volatile metabolites}

Studies on the effect of volatile and non-volatile metabolites of Trichoderma species indicated that the mycelial growth of the pathogen was minimum (20.7 and $17.3 \mathrm{~mm}$, respectively) and the inhibition was maximum (76.7 and $80.5 \%$, respectively) with the isolate $\mathrm{TVC}_{3}$ followed by $\mathrm{THC}_{1}$ (Table 3 ).

Table 3. In vitro antagonistic potential of Trichoderma species against $P$. aphanidermatum through volatile and non-volatile metabolites.

\begin{tabular}{lcccc}
\hline \multirow{2}{*}{ Treatment } & \multicolumn{2}{c}{ Volatiles } & \multicolumn{2}{c}{ Non-volatiles } \\
\cline { 2 - 5 } & $\begin{array}{c}\text { Mycelial growth of } \\
\text { pathogen (mm) }\end{array}$ & $\begin{array}{c}\text { Reduction over } \\
\text { control (\%) }\end{array}$ & $\begin{array}{c}\text { Mycelial growth of } \\
\text { pathogen (mm) }\end{array}$ & $\begin{array}{c}\text { Reduction over } \\
\text { control (\%) }\end{array}$ \\
\hline $\mathrm{TVC}_{1}$ & $34.3 \mathrm{~d}$ & 61.3 & $29.7 \mathrm{~d}^{1}$ & 66.6 \\
$\mathrm{TVC}_{2}$ & $53.3 \mathrm{~h}$ & 40.0 & $40.0 \mathrm{~h}$ & 55.5 \\
$\mathrm{TVC}_{3}$ & $20.7 \mathrm{a}$ & 76.7 & $17.3 \mathrm{a}$ & 80.5 \\
$\mathrm{TVC}_{4}$ & $38.0 \mathrm{e}$ & 57.2 & $33.0 \mathrm{e}$ & 62.8 \\
$\mathrm{TVC}_{5}$ & $29.3 \mathrm{c}$ & 67.0 & $24.7 \mathrm{c}$ & 72.2 \\
$\mathrm{THC}_{1}$ & $25.0 \mathrm{~b}$ & 71.8 & $22.7 \mathrm{~b}$ & 74.4 \\
$\mathrm{THC}_{2}$ & $46.7 \mathrm{~g}$ & 47.4 & $38.3 \mathrm{~g}$ & 56.8 \\
$\mathrm{THC}_{3}$ & $41.3 \mathrm{f}$ & 53.4 & $35.7 \mathrm{f}$ & 59.8 \\
$\mathrm{Control}$ & $88.7 \mathrm{i}$ & - & $88.7 \mathrm{i}$ & - \\
\hline
\end{tabular}

TVC: Trichoderma viride from chilli rhizosphere, THC: Trichoderma harzianum from chilli rhizosphere.

${ }^{1}$ Means of four replicates. Values in each column followed by the same letter are not significantly different according to the DMRT method (P $\left.<0.05\right)$.

Culture filtrate on the mycelial growth of $\boldsymbol{P}$. of $P$. aphanidermatum at $15 \%$ concentration and the least aphanidermatum inhibition on the mycelial growth of $P$. aphanidermatum was

The results revealed that the culture filtrate of the observed with $5 \%$ concentration by the isolate $\mathrm{TVC}_{2}$ (Table isolate $\mathrm{TVC}_{3}, \mathrm{TVC}_{5}$, and $\mathrm{THC}_{1}$ recorded complete inhibition 4).

Table 4. Effect of culture filtrates on the mycelial growth of $P$. aphanidermatum.

\begin{tabular}{|c|c|c|c|c|c|c|}
\hline \multirow{3}{*}{ Treatment } & \multicolumn{6}{|c|}{ Concentration of culture filtrate (\%) } \\
\hline & \multicolumn{2}{|l|}{5} & \multicolumn{2}{|c|}{10} & \multicolumn{2}{|c|}{15} \\
\hline & $\begin{array}{l}\text { Mycelial growth } \\
\text { of pathogen (mm) }\end{array}$ & $\begin{array}{l}\text { Reduction over } \\
\text { control }(\%)\end{array}$ & $\begin{array}{l}\text { Mycelial growth } \\
\text { of pathogen }(\mathrm{mm})\end{array}$ & $\begin{array}{l}\text { Reduction over } \\
\text { control }(\%)\end{array}$ & $\begin{array}{l}\text { Mycelial growth } \\
\text { of pathogen }(\mathrm{mm})\end{array}$ & $\begin{array}{l}\text { Reduction over } \\
\text { control }(\%)\end{array}$ \\
\hline $\mathrm{TVC}_{1}$ & $28.0 \mathrm{~d}^{1}$ & 68.2 & $18.3 \mathrm{~d}^{1}$ & 79.3 & $9.0 \mathrm{~b}^{1}$ & 90.0 \\
\hline $\mathrm{TVC}_{2}$ & $40.0 \mathrm{~h}$ & 54.5 & $31.7 \mathrm{~h}$ & 64.1 & $26.3 \mathrm{f}$ & 70.3 \\
\hline $\mathrm{TVC}_{3}$ & $17.3 \mathrm{a}$ & 80.3 & $9.0 \mathrm{a}$ & 89.8 & $0.0 \mathrm{a}$ & 100.0 \\
\hline $\mathrm{TVC}_{4}$ & $31.7 \mathrm{e}$ & 64.0 & $22.3 \mathrm{e}$ & 74.7 & $14.7 \mathrm{c}$ & 83.4 \\
\hline $\mathrm{TVC}_{5}$ & $23.0 \mathrm{c}$ & 74.0 & $11.7 \mathrm{~b}$ & 86.7 & $0.0 \mathrm{a}$ & 100.0 \\
\hline $\mathrm{THC}_{1}$ & $21.7 \mathrm{~b}$ & 75.4 & $10.3 \mathrm{~b}$ & 88.3 & $0.0 \mathrm{a}$ & 100.0 \\
\hline $\mathrm{THC}_{2}$ & $38.0 \mathrm{~g}$ & 57.0 & $27.0 \mathrm{~g}$ & 69.4 & $21.0 \mathrm{e}$ & 76.3 \\
\hline $\mathrm{THC}_{3}$ & $35.3 \mathrm{f}$ & 60.0 & $24.3 \mathrm{f}$ & 72.5 & $18.7 \mathrm{~d}$ & 79.0 \\
\hline Control & $88.0 \mathrm{i}$ & - & $88.3 \mathrm{i}$ & - & $88.7 \mathrm{~g}$ & - \\
\hline
\end{tabular}

TVC: Trichoderma viride from chilli rhizosphere, THC: Trichoderma harzianum from chilli rhizosphere.

${ }^{1}$ Means of four replicates. Values in each column followed by the same letter are not significantly different according to the DMRT method $(\mathrm{P}<0.05)$. 


\section{Plant growth promotion}

The effects of culture filtrate of the antagonists on chilli seed germination and growth promotion are presented in Table 5. The culture filtrate of all the Trichoderma species increased the germination, besides increasing the shoot and root length of chilli seedlings after 15 days of inoculation. Among the isolates, isolate
$\mathrm{TVC}_{3}$ recorded maximum germination percentage (95.0\%), shoot $(4.3 \mathrm{~cm})$ and root length $(9.2 \mathrm{~cm})$ compared to control $(79.3 \% ; 1.3$ and $6.7 \mathrm{~cm}$, respectively). This was followed by $\mathrm{THC}_{1}(93.0 \% ; 4.1$ and $9.0 \mathrm{~cm}$, respectively). Whereas, the chilli seeds treated with sterile water exhibited lowest germination percentage and plant growth.

Table 5. Evaluation of Trichoderma species on chilli seedling growth.

\begin{tabular}{|c|c|c|c|c|}
\hline Treatment & $\begin{array}{c}\text { Germination } \\
(\%)\end{array}$ & $\begin{array}{c}\text { Shoot length } \\
(\mathrm{cm})\end{array}$ & $\begin{array}{l}\text { Root length } \\
\text { (cm) }\end{array}$ & $\begin{array}{l}\text { Vigour } \\
\text { index }\end{array}$ \\
\hline $\mathrm{TVC}_{1}$ & $89.0 \mathrm{~d}^{1}$ & $3.8 \mathrm{c}^{1}$ & $8.6 \mathrm{~d}^{1}$ & $1103 \mathrm{~d}^{1}$ \\
\hline $\mathrm{TVC}_{2}$ & $84.0 \mathrm{~g}$ & $3.1 \mathrm{~g}$ & $8.0 \mathrm{~g}$ & $932 \mathrm{~h}$ \\
\hline $\mathrm{TVC}_{3}$ & $95.0 \mathrm{a}$ & $4.3 \mathrm{a}$ & $9.2 \mathrm{a}$ & $1283 \mathrm{a}$ \\
\hline $\mathrm{TVC}_{4}$ & $88.0 \mathrm{~d}$ & $3.6 \mathrm{~d}$ & $8.5 \mathrm{~d}$ & $1065 \mathrm{e}$ \\
\hline $\mathrm{TVC}_{5}$ & $91.3 \mathrm{c}$ & $3.9 \mathrm{c}$ & $8.8 \mathrm{c}$ & $1160 \mathrm{c}$ \\
\hline $\mathrm{THC}_{1}$ & $93.0 \mathrm{~b}$ & $4.1 \mathrm{~b}$ & $9.0 \mathrm{~b}$ & $1218 b$ \\
\hline $\mathrm{THC}_{2}$ & $85.0 \mathrm{f}$ & $3.3 \mathrm{f}$ & $8.2 \mathrm{f}$ & $975 \mathrm{~g}$ \\
\hline $\mathrm{THC}_{3}$ & $87.3 \mathrm{e}$ & $3.5 \mathrm{e}$ & $8.4 \mathrm{e}$ & $1039 \mathrm{f}$ \\
\hline Control & $79.3 \mathrm{e}$ & $1.3 \mathrm{~h}$ & $6.7 \mathrm{~h}$ & $503 \mathrm{i}$ \\
\hline
\end{tabular}

\section{DISCUSSION}

Chilli damping-off is a very serious disease causing severe loss to chilli production. Management of chilli damping-off with cultural practices and toxic chemicals has both advantages and disadvantages. Late managing this disease by biological methods has become increasingly important. Among biological control methods, Trichoderma are an alternative to chemical pesticides that can be more reliable and ecologically as well as economically sustainable. All the isolates of Trichoderma species reduced the mycelial growth of $P$. aphanidermatum. Among these, $\mathrm{TVC}_{3}, \mathrm{THC}_{1}$ was highly antagonistic to $P$. aphanidermatum.

Trichoderma species clearly exhibited varying levels of antagonism towards $P$. aphanidermatum. A specificity of biocontrol agents against the pathogens was also evident. The antagonists isolated from chilli rhizosphere performed better in inhibiting the growth of $P$. aphanidermatum. This is in consistent with earlier findings (22). Similarly, T. viride inhibited the growth of $P$. aphanidermatum in tomato (16); in turmeric (33) and many hosts (21). Volatile and non volatile antibiotics produced by $T$. viride and mycoparasitism might be responsible for the suppression of $P$. aphanidermatum leading to lysis $(7,8,10)$.

In this study growth characters, conidial morphology, spore intensity and size could separate Trichoderma species $\mathrm{TVC}_{3}$ from other species. Recently, Trichoderma sp. 1 can be distinguished from other Trichoderma species by the characters of colony morphology, phialide, conidial morphology and size (26). Similar observation was made by several workers $(3,28)$.

Volatile and non-volatile metabolites produced by different species of Trichoderma indicated that the isolate $\mathrm{TVC}_{3}$ effectively inhibited the mycelial growth of $P$. aphanidermatum under in vitro. Similarly, Trichoderma isolate- $\mathrm{T}_{7}$ was effective in inhibiting Pythium sp. by producing both volatile and non-volatile inhibitors (31). In addition, 
antimicrobial metabolites produced by Trichoderma species were effective against Fusarium oxysporum, Rhizoctonia solani and Colletotrichum gloeosporioides (40). The volatile secondary metabolites such as ethylene, hydrogen cyanide, aldehyde and ketones produced by Trichoderma spp., were responsible for the suppression of plant pathogens $(29,34)$. Similarly, the production of antibiotics, cell wall degrading enzymes and competition for space and nutrients by Trichoderma spp., was solely responsible for the suppression of $P$. aphanidermatum $(10,17,36)$. This is in accordance with our results of earlier workers.

The present study also indicated that the mycelial growth of $P$. aphanidermatum was reduced with the increase in concentration of culture filtrates. The isolate $\mathrm{TVC}_{3}$ was found to be the most effective in inhibited the mycelial growth of $P$. aphanidermatum. Similarly, the results indicated that 10 days old culture filtrate of $T$. viride exhibited maximum inhibition of $P$. indicum under in vitro (24). The overall results indicated that the pathogen $P$. aphanidermatum was highly affected by all isolates of Trichoderma under in vitro conditions. Antagonism of Trichoderma species against several soil-borne plant pathogens has been reported by several workers $(2,11)$.

The antagonist Trichoderma not only suppresses the growth of pathogen and also control the disease, but also has got its growth promoting effect in the plants. In the present study revealed that the chilli seeds treated with culture filtrates of the antagonists increased the seed germination and induced the plant growth promotion under in vitro. The shoot length, root length and vigour index of chilli was significantly more in culture filtrate of the isolate $\mathrm{TVC}_{3}$. The growth promotion exerted by Trichoderma might be due to the production of auxin-like compounds in the culture medium $(35,37)$. Similar beneficial effects on seed germination and seedling vigour was observed with inoculation of Trichoderma spp. has been previously reported $(13,25)$.

In the present study Trichoderma species were isolated from chili rhizosphere $\left(\mathrm{TVC}_{3}\right)$ was found to be highly effective in inhibiting the mycelial growth of pathogen and increased the plant growth.

\section{ACKNOWLEDGEMENTS}

The authors wish to thank Prof. Dr.P.N.Chowdhry, the principal scientist, National Centre of Fungal Taxonomy (NCFT), Indian Agricultural Research Institute (IARI), New Delhi for his encouragement, the facilities provided and for reviewing the manuscript.

\section{REFERENCES}

1. Abdul Bavi, A.A.; Anderson, J.D. (1973). Vigour determination in soyabean seed by multiple criteria. Crop Sci. 13, 630-633.

2. Benitez, T.; Rincon, A.M.; Limon, M.C.; Codon, A.C. (2004). Biocontrol mechanism of Trichoderma strains. Int. Microbiol. 7, 249-260.

3. Choi, I.Y.; Hong, S.B.; Yadav, M.C. (2003). Molecular and morphological characterization of green mold, Trichoderma spp. isolated from oyster mushrooms. Mycobiol. 31, 74-80.

4. Dennis, C.; Webster, J. (1971a). Antagonistic properties of species group of Trichoderma I. Production of non-volatile antibiotics. Trans. Brit. Mycol. Soc. 57, 25-30.

5. Dennis, C.; Webster, J. (1971b). Antagonistic properties of species group of Trichoderma II. Production of non-volatile antibiotics. Trans. Brit. Mycol. Soc. 57, 41-48.

6. Elad, Y.; Chet, I. (1983). Improved selective media for isolation of Trichoderma or Fusarium spp. Phytoparasitica. 11, 55-58.

7. El-Katatny, M.H.; Gudelij, M.; Robra, K.H.; Elnaghy, M.A.; Gubitz, G.M. (2001). Characterization of a chitinase and an endo-b-1,3glucanase from Trichoderma harzianum Rifai $\mathrm{T}_{24}$ involved in control of the phytopathogen Sclerotium rolfsii. Appl. Microbiol. Biotechnol. 56, 137-143.

8. Eziashi, E.I.; Omamor, I.B.; Odigie, E.E. (2007). Antagonism of Trichoderma viride and effects of extracted water soluble compounds from Trichoderma species and benlate solution on Ceratocystis paradoxa. African J. Biotechnol. 6, 388-392.

9. Eziashi, E.I.; Uma, N.U.; Adekunle, A.A.; Airede, C.E. (2006). Effect of metabolites produced by Trichoderma species against Ceratocystis paradoxa in culture medium. African J. Biotechnol. 5, 703-706.

10. Ghildiyal, A.; Pandey, A. (2008). Isolation of cold tolerant antifungal strains of Trichoderma species from glacial sites of Indian Himalayan 
region. Res. J. Microbiol. 8, 559-564.

11. Hajiehhrari, B.; Torabi-Giglou, M.; Mohammadi, M.R.; Davari, M. (2008). Biocontrol potential of some Iranian Trichoderma isolates in the control of soil-borne plant pathogenic fungi. African J. Biotechnol. 7, 967-972.

12. ISTA, (1993). Proceedings of international seed test association, rules for seed testing. Seed Sci. Technol. 21, 1-152.

13. Jadhav, V.T.; Ambadkar, C.V. (2007). Effect of Trichoderma spp. on seedling emergence and seedling mortality of tomato, chilli and brinjal. J. Pl. Dis. Sci. 2, 190-192.

14. Jayaraj, J.; Radhakrishnan, N.V; Velazhahan, R. (2006). Development of formulations of Trichoderma harzianum strain M1 for control of damping-off of tomato caused by Pythium aphanidermatum. Arch. Phytopathol. Pl. Prot. 39, 1-8.

15. Kanjanamaneesathian, M.; Phetcharat, V.; Pengnoo, A.; Upawan, S. (2003). Use of Trichoderma harzianum cultured on ground mesocarp fibre of oil-palm as seed treatment to control Pythium aphanidermatum, a causal agent of damping-off of Chinese kale seedling. World J. Microbiol. Biotechnol. 19, 825-829.

16. Karpagavalli, S.; Ramabadran, R. (2001). Effect of fungicides and Trichoderma species on cellulolytic enzyme production, damping-off incidence and seedling vigour of tomato. Pl. Dis. Res. 16, 179-185.

17. Khare, A.; Singh, B.K.; Upadhyay, R.S. (2010). Biological control of Pythium aphanidermatum causing damping off of mustard by mutants of Trichoderma viride-1433. J. Agricultural Technol. 6, 231-243.

18. Khare, A.; Upadhyay, R.S. (2009). Induction of mutant strains of Trichoderma viride 1433 for biocontrol of Pythium aphanidermatum. Environ. Biol. Conservation. 14, 21-27.

19. Le, H.T.; Black, L.L.; Sikora, R.A. (2003). Evaluation of Trichoderma species for biocontrol of tomato sudden caused by Pythium aphanidermatum following flooding in tropical hot season. Communications in Agricultural Appl. Biol. Sci. 68, 463-474.

20. Manoranjitham, S.K.; Prakasam, V.; Rajappan, K.; Amutha, G. (2000). Control of chilli damping-off using bioagents. J. Mycol. Pl. Pathol. 30, 225-228.

21. Mishra, V.K. (2010). In vitro antagonism of Trichoderma species against Pythium aphanidermatum. J. Phytology. 2, 28-35.

22. Mohamed, H.A.L.; Haggag, W.M. (2006). Biocontrol potential of salinity tolerant mutants of Trichoderma harzianum against Fusarium oxysporum. Brazilian J. Microbiol. 37, 181-191.

23. Muthukumar, A.; Eswaran, A.; Sanjeevkumar, K. (2008). Biological control of Pythium aphanidermatum (Edson.) Fitz. Mysore J. Agric. Sci. $42,20-25$.

24. Naseby, D.C.; Pascual, J.A.; Lynch, J.M. (2000). Effect of biocontrol strains of Trichoderma on plant growth, Pythium ultimum population, soil microbial communities and soil enzyme activities. J. Appl.
Microbiol. 88, 161-169.

25. Neelamegam, R. (2004). Evaluation of fungal antagonists to control damping-off of tomato (Lycopersicon esculentum Mill.) caused by Pythium ultimum. J. Biol. Control. 18, 97-102.

26. Neelamegam, R. (2005). Effect of different organic matter sources and Trichoderma viride on damping-off of tomato var. Co-1 seedlings caused by Pythium indicum. J. Biol. Control. 19, 149-155.

27. Park, M.S.; Seo, G.S.; Lee, K.H.; Bae, K.S.; Yu, S.H. (2005). Morphological and cultural characteristics of Trichoderma spp. associated with green mold of oyster mushroom in Korea. Plant Pathol. J. 21, 221-228.

28. Samuels, G.J. (1996). Trichoderma: a review of biology and systematic of the genus. Mycol. Re. 100, 923-935.

29. Samuels, G.J.; Dodd, S.L.; Gams, W.; Castleburry, L.A.; Petrini, O. (2002). Trichoderma species associated with the green mold epidemic of commercially grown Agaricus bisporus. Mycologia. 94, 146-170.

30. Schirmbock, M.; Lortio, M.; Wang, Y.L.; Hayes, C.K.; Arisan-Atac, I.; Scala, F.; Harman, G.E.; Kubicek, C.P. (1994). Parallel formation and synergism of hydrolytic enzymes and peptaibol antibiotics, molecular mechanisms involved in the antagonistic action of Trichoderma harzianum against phytopathogenic fungi. Appl. Environ. Microbiol. 60, 4364-4370.

31. Senda, M.; Senda, K.; Kageyama, H.; Suga, Levesque, A. (2009). Two new species of Pythium, Pythium senticosum and Pythium takayamanum, isolated from cool-temperate forest soil in Japan. Mycologia. 101, 439448.

32. Sitansu Pan, Someshwar Bhagat, (2008). Characterization of antagonistic potential of Trichoderma spp. against some soil-borne plant pathogens. $J$. Biol. Control. 22, 43-49.

33. Upadhyay, R.S.; Rai, B. (1987). Studies on antagonism between Fusarium udum Butler and root region microflora of pigeonpea. Plant and Soil. 101, 79-93.

34. Ushamalini, C.; Nakkeeran, S.; Marimuthu, T. (2008). Development of biomanure for the management of turmeric rhizome rot caused by Pythium aphanidermatum. Arch. Phytopathol. Pl. Prot. 41, 365-378.

35. Vey, A.; Hoagland, R.E.; Butt, T.M. (2001). Toxic metabolites of fungal biocontrol agents. Fungi as biocontrol agents: Progress, Problems and Potential. Butt, T.M.; Jackson, C.N. (eds), CAB International, Bristol. p 311-346.

36. Vinale, F.; Ambrosio, G.; Abadi, K.; Scala, F.; Marra, R.; Turra, D.; Woo, S.L.; Lortio, M. (2004). Application of Trichoderma harzianum $\left(\mathrm{T}_{22}\right)$ and Trichoderma atroviride $\left(\mathrm{P}_{1}\right)$ as plant growth promoters and their compatibility with copper oxy chloride. J. Zhejiang University Science. 30, 2-8.

37. Vinale, F.; Marra, R.; Scala, F.; Ghisalberti, E.L.; Lortio, M.; Sivasithambaram, K. (2006). Major secondary metabolites produced by 
two commercial Trichoderma strains active against different phytopathogens. Lett. Appl. Microbiol. 43, 143-148.

38. Vinale, F.; Sivasithambaram, K.; Ghisalberti, L.E.; Marra, R.; Woo, S.L.; Lortio, M. (2008). Trichoderma-plant pathogen interactions. Soil Biol. Biochem. 40, 1-10.
39. Vincent, J.M. (1929). Distribution of fungal hyphae in the presence of certain inhibitors. Nature. $159,850$.

40. Waterhouse, G.M. (1968). The genus Pythium Pringsheim. Mycol. Papers. 110, 1-50. 